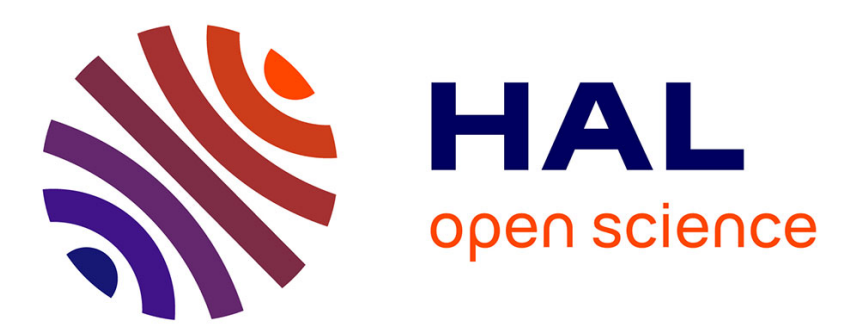

\title{
Capillary suction effects on surface-wave dispersion in partially saturated soils
}

\author{
Santiago Solazzi, Ludovic Bodet, Klaus Holliger, Damien Jougnot
}

\section{To cite this version:}

Santiago Solazzi, Ludovic Bodet, Klaus Holliger, Damien Jougnot. Capillary suction effects on surfacewave dispersion in partially saturated soils. EGU General Assembly 2021, Apr 2021, online, France. 10.5194/egusphere-egu21-12197 . hal-03184985

\section{HAL Id: hal-03184985 https://hal.sorbonne-universite.fr/hal-03184985}

Submitted on 30 Mar 2021

HAL is a multi-disciplinary open access archive for the deposit and dissemination of scientific research documents, whether they are published or not. The documents may come from teaching and research institutions in France or abroad, or from public or private research centers.
L'archive ouverte pluridisciplinaire HAL, est destinée au dépôt et à la diffusion de documents scientifiques de niveau recherche, publiés ou non, émanant des établissements d'enseignement et de recherche français ou étrangers, des laboratoires publics ou privés. 
EGU21-12197

https://doi.org/10.5194/egusphere-egu21-12197

EGU General Assembly 2021

(c) Author(s) 2021. This work is distributed under

the Creative Commons Attribution 4.0 License.

\section{Capillary suction effects on surface-wave dispersion in partially saturated soils}

Santiago Solazzi ${ }^{1}$, Ludovic Bodet ${ }^{2}$, Klaus Holliger ${ }^{1}$, and Damien Jougnot ${ }^{2}$

${ }^{1}$ Institute of Earth Sciences, University of Lausanne, Lausanne, Switzerland

${ }^{2}$ UMR 7619 METIS, Sorbonne University - CNRS, Paris, France

Estimation of water content in the shallow subsurface using seismic data is a complex task of increasing importance in the overall field of hydrogeophysics. In this context, the velocities of compressional $\left(V_{p}\right)$ and shear $\left(V_{s}\right)$ waves can be used to infer strong water content variations in unconsolidated soils, such as, the presence of the water table, by means of $\mathrm{V}_{\mathrm{p}} / \mathrm{V}_{\mathrm{s}}$ ratio estimations. This approach, which is based on first-arrival time data, generally does not permit a proper quantification of the water content distribution in the partially saturated zone. Conversely, field and laboratory measurements indicate that surface-waves are indeed remarkably sensitive to both the water table depth and the saturation characteristics in the overlaying capillary fringe. This apparent difference in sensitivity between body and surface waves cannot be explained using conventional models. Observations and experiments show that the effective stress of unconsolidated porous media is not only affected by the overburden stress and pore pressures, as classic models assume, but also by capillary forces, which tend to stiffen the soil at relatively low saturations. In this work, we extend seminal rock physics models to include capillary suction effects in the effective stress of the soil. This approach provides effective elastic moduli and, thus, $V_{p}$ and $V_{s}$, which are depth- and saturation-dependent. Then, we solve the quasi-static fluid flow equations in a porous medium and obtain saturation profiles for a given water table depth. This information, combined with the proposed rock physics model, permits to simulate simple seismic data sets, that is, body-wave first-arrival times and surface-wave phase velocities, for different water table depths and soil textures. Our results clearly show that capillary effects allow to explain the apparent difference in sensitivity between body- and surface-wave signatures in response to small water content variations in the partially saturated zone. Capillary effects are primarily relevant in porous media composed by relatively small characteristic grain sizes. We conclude that the proposed framework has the potential to fundamentally improve our characterization of nearsurface environments using both active and passive seismic methods. 